\title{
STORAGE OF SEROTONIN IN VIVO AS A COMPLEX WITH SEROTONIN-BINDING PROTEIN IN CENTRAL AND PERIPHERAL SEROTONERGIC NEURONS ${ }^{1}$
}

\author{
M. D. GERSHON ${ }^{*, 2}$ K. P. IIU $\ddagger$ S. E. KARPIAK, $\ddagger$ AND H. TAMIR $\ddagger$ \\ ${ }^{*}$ Departments of Anatomy and Cell Biology and Psychiatry, Columbia University, College of Physicians and Surgeons, and $\ddagger$ New \\ York State Psychiatric Institute, Division of Neuroscience, New York, New York 10032
}

Received January 12, 1983; Revised March 29, 1983; Accepted March 31, 1983

\begin{abstract}
Serotonin-binding protein (SBP) is a soluble protein found in synaptic vesicles of central and peripheral serotonergic neurons. Experiments were undertaken to determine whether serotonin (5$\mathrm{HT}$ ) is physiologically stored as a complex with SBP in vivo. $\left[{ }^{3} \mathrm{H}\right] 5-\mathrm{H}^{\prime} \mathrm{T}$ was used as a probe. Neurons were allowed to specifically take up the labeled amine and attempts were made to recover the in vivo formed $\left[{ }^{3} \mathrm{H}\right] 5-\mathrm{HT} \cdot \mathrm{SBP}$ complex. Rats were perfused intraventricularly $(3 \mathrm{hr})$ with $\left[{ }^{3} \mathrm{H}\right] 5-\mathrm{HT}$. Strips of rabbit enteric nervous system (ENS) were incubated with $\left[{ }^{3} \mathrm{H}\right] 5-\mathrm{HT}$ in the presence of desipramine. The tissues were then homogenized so as to disrupt synaptic vesicles; protein-bound $\left[{ }^{3} \mathrm{H}\right] 5-\mathrm{HT}$ was obtained from the $100,000 \times g$ supernatant by filtration on Sephadex G-50 and subjected to sodium dodecyl sulfate-polyacrylamide gel electrophoresis (SDS-PAGE). Studies with $\left[{ }^{3} \mathrm{H}\right] 5-\mathrm{HT}$ added just prior to homogenization indicated that the $\left[{ }^{3} \mathrm{H}\right] 5-\mathrm{HT} \cdot \mathrm{SBP}$ complex had formed intraneuronally, prior to homogenization. The protein $\cdot\left[{ }^{3} \mathrm{H}\right] 5$ - $\mathrm{HT}$ complexes from brain and gut migrated on the gels with apparent molecular weights of 45,000 and 56,000, corresponding to those measured by SDS-PAGE for purified SBP; however, the 45-kilodalton (kd) molecule predominated when the SBP complex was formed in vivo, whereas the $56-\mathrm{kd}$ molecule predominated when the SBP $\cdot\left[{ }^{3} \mathrm{H}\right] 5-\mathrm{HT}$ complex was formed with extracted SBP. It is possible that the 56 -kd SBP is characteristic of the molecule in perikarya or nonterminal axons, whereas the 45-kd molecule is characteristic of terminal varicosities because radioautographic results show that in both the central nervous system and ENS, $\left[{ }^{3} \mathrm{H}\right] 5-\mathrm{HT}$ is mostly concentrated in terminals. In any case, newly taken up $\left[{ }^{3} \mathrm{H}\right] 5$-HT preferentially labels $45-\mathrm{kd}$ SBP. Depletion of endogenous 5 - $\mathrm{HT}$ by placing animals on a tryptophan-deficient diet increased the amount of exogenous $\left[{ }^{3} \mathrm{H}\right] 5-\mathrm{HT}$ bound to SBP in vivo. This suggests that endogenous 5 - $\mathrm{HT}$ is normally bound to SBP and competes with the $\left[{ }^{3} \mathrm{H}\right] 5-\mathrm{HT}$ probe for available binding sites. The binding of 5-HT to SBP within vesicles may be important to reduce the osmotic pressure that would build up in synaptic vesicles if 5-HT were free in solution.
\end{abstract}

Serotonin-binding protein (SBP), a protein that preferentially binds serotonin $\left(5-\mathrm{H}^{\prime} \mathrm{T}\right)$, has previously been found to be a constituent of central and peripheral serotonergic neurons ('Tamir and Huang, 1974; Tamir and Kuhar, 1975; Jonakait et al., 1977). Thus, the protein can be detected in the brain and spinal cord, where its distribution parallels that of 5-HT (Tamir and Gershon,

\footnotetext{
${ }^{1}$ This work was supported in part by National Science Foundation Grant 09335 and National Institutes of Health Grant NS12969. We wish to thank Ms. Diane Sherman for excellent assistance with electron microscopy.

${ }^{2}$ To whom correspondence should be addressed, at Department of Anatomy and Cell Biology, Columbia University, College of Physicians and Surgeons, 630 West 168th Street, New York, NY 10032.
}

1979), and in the neural layers of the gastrointestinal tract (Jonakait et al., 1977, 1979). Lesions of the raphe nuclei deplete SBP in the forebrain (Tamir and Kuhar, 1975); transection of the spinal cord depletes SBP distal to the lesion while causing a proximal accumulation of the protein (Tamir and Gershon, 1979); 5,7-dihydroxytryptamine treatment depletes SBP from the small intestine (Jonakait et al., 1977). The protein, moreover, appears to be neurectoderm specific. It is encountered in serotonergic neurons and in the neural crest-derived parafollicular cells of the thyroid gland, which store 5HT (Bernd et al., 1981); however, SBP cannot be detected in 5-HT-storing enteroendocrine cells (Gold et al., 1982), which are of entodermal origin, or in mast cells or platelets, which are derived embryologically from mesoderm (Huang et al., 1982; Tamir et al., 1980, 1981, 1982a). 
SBP is probably a component of 5-HT storage vesicles. Evidence that favors this conclusion includes the following observations. ( $i$ ) SBP accumulates above a spinal cord lesion at a rate consistent with fast axonal transport (Tamir and Gershon, 1979). Fast transport is associated with membrane-enclosed or membranous components destined for the synaptic apparatus (Grafstein, 1977). (ii) SBP is enriched 4-fold over the synaptosomal supernatant in a vesicular fraction derived from synaptosomes (Tamir and Gershon, 1979). (iii) SBP is released in a $\mathrm{Ca}^{2+}$-dependent manner, along with 5 -HT, by electrical stimulation of enteric neurons, whereas the cytosol marker, lactic acid dehydrogenase, is not (Jonakait et al., 1979). This protein release implies that exocytosis is the SBP release mechanism and that, in turn, implies an intravesicular localization of the stored SBP.

Our working hypothesis is that SBP functions as a storage protein within serotonergic vesicles. The binding of the amine to the protein may reduce osmotic pressure within the vesicles. It has been estimated from studies of enteric serotonergic neurons in organotypic tissue cultures that the intracellular concentration of 5 - $\mathrm{HT}$ is quite high, about $7 \mathrm{~mm}$ (Liu et al., 1982). The intravesicular concentration is likely to be higher still. Thus there must be some mechanism to prevent osmotic swelling of vesicles. This could be accomplished if one molecule of SBP bound several molecules of 5-HT. Properties of SBP that have been established indicate that the molecule is remarkably well suited to a role as a storage protein. The binding of 5-HT by SBP is extremely tight under intracellular conditions. In $\mathrm{K}^{+}$- and $\mathrm{Fe}^{2+}$-containing buffers a dissociation constant has been measured in the range of $10^{-10} \mathrm{M}$ (Jonakait et al., 1977; Gershon and Tamir, 1981a). In the presence of $\mathrm{Na}^{+}$or $\mathrm{Ca}^{2+}$, however, SBP loses its affinity for 5-HT (Tamir et al., 1976; Gershon and Tamir, 1981a). It is therefore likely that very little free 5 - $\mathrm{HT}$ will be in equilibrium with intracellular SBP until the protein is saturated. On the other hand, exposure of SBP to extracellular fluid at the time of exocytosis would cause 5-HT to dissociate from the protein so as to be free to diffuse to its receptors.

The current study was undertaken in order to test the hypothesis that $5-\mathrm{HT}$ is bound to SBP in serotonergic neurons in vivo. We have sought to determine whether newly taken up $\left[{ }^{3} \mathrm{H}\right] 5-\mathrm{HT}$ can be recovered from central and peripheral neurons as a complex with SBP. In addition, we have analyzed the effect of lowering the concentration of endogenous 5-HT on the capacity of SBP to bind exogenous $\left[{ }^{3} \mathrm{H}\right] 5-\mathrm{HT}$ in vivo. 5 -HT was depleted for this purpose by putting animals on a tryptophan-free diet to avoid the use of drugs such as reserpine and indole neurotoxins that may deplete $5-\mathrm{HT}$, in part, through an action on SBP.

\section{Materials and Methods}

\section{Intraventrical perfusion of $\left[{ }^{3} H\right] 5-H T$}

Rats, pretreated with clorgyline, $(25 \mathrm{mg} / \mathrm{kg}$, i.p.; 30 min) were anesthetized lightly with ether and mounted in a small animal stereotaxic apparatus (Kopf No. 900). A midline incision was made in the scalp and burr holes, $1 \mathrm{~mm}$ diameter, were made in the skull, $2 \mathrm{~mm}$ to the left and right of the midline on bregma. Perfusion of $\left[{ }^{3} \mathrm{H}\right] 5$ HT was done through a 25 gauge needle that was stereotaxically inserted into a lateral ventricle through the burr hole(s) to an average depth of 4 to $6 \mathrm{~mm}$ from the cortical surface. The perfusion (using a Sage pump, No. B41A) was carried on for 2.5 to $3.0 \mathrm{hr}$, using $\left[{ }^{3} \mathrm{H}\right] 5-\mathrm{HT}$ $\left(12 \mathrm{Ci} / \mathrm{mmol} ; 10^{-4} \mathrm{M} ; 0.5 \mathrm{ml}\right)$. Half the volume was given into the left lateral ventricle (for the first $1.5 \mathrm{hr}$ ) and the remaining volume was given into the right lateral ventricle. The rats were kept under light ether anesthesia throughout the perfusion and the animals were constatly monitored to determine whether there was any efflux (backflow) from the cannula. At the end of the perfusion period the animal was decapitated and the brain (without cercbcllum) was immediately removed and processed as described below.

Isolation of brain SBP. ${ }^{3} H J 5-H T$ complex. The perfused rat brain was rinsed with $0.32 \mathrm{M}$ sucrose in $1 \mathrm{mM}$ potassium phosphate buffer, $\mathrm{pH} 7.5$, and homogenized in $5.0 \mathrm{ml}$ of the same buffer. 'I'he homogenate was centrifuged at $100,000 \times \mathrm{g}$ for $20 \mathrm{~min}$. A sample was removed, acidified, and stored frozen until assays of its concentration of $\left[{ }^{3} \mathrm{H}\right] 5-\mathrm{HT}$ and $5-\left[{ }^{3} \mathrm{H}\right]$ hydroxyindolacetic acid ( $\left[{ }^{3} \mathrm{H}\right] 5$-HIAA) could be performed. The $\left[{ }^{3} \mathrm{H}\right] 5-\mathrm{HT}$ that bound to protein in vivo was separated from free $\left[{ }^{3} \mathrm{H}\right] 5$ HT by passing $0.5 \mathrm{ml}$ of the $100,000 \times g$ supernatant through a column of Sephadex G-50 $(1 \times 10 \mathrm{~cm})$. An aliquot of the separated $\left[{ }^{3} \mathrm{H}\right] 5-\mathrm{HT} \cdot \mathrm{SBP}$ complex was subjected to SDS-10\% PAGE as previously described (Tamir et al., 1980; Tamir, 1982). To control for the possibility that the $\left[{ }^{3} \mathrm{H}\right] 5-\mathrm{HT} \cdot \mathrm{SBP}$ complex actually formed during the homogenization of the brain and subsequent steps of centrifugation and not in vivo, we added $\left[{ }^{3} \mathrm{H}\right] 5-\mathrm{HT}$, at the concentration found in the brains of perfused rats at the time of decapitation, to a nonperfused brain just before homogenization. The homogenization, centrifugation, and Sephadex column chromatography were then carried out identically as for perfused brains. Less than $10 \%$ of the counts found to be bound to protein isolated from animals perfused with $\left[{ }^{3} \mathrm{H}\right] 5-\mathrm{HT}$ in vivo were found to be bound to protein when the $\left[{ }^{3} \mathrm{H}\right]$ 5 -HT was added just prior to homogenization. The $\left[{ }^{3} \mathrm{H}\right]$ 5-HT.SBP complex was also prepared from protein extracted from unlabeled tissue for comparison with the material formed in vivo by incubating partially purified SBP (from which endogenous 5-HT had been removed by extensive dialysis) with $\left[{ }^{3} \mathrm{H}\right] 5-\mathrm{HT}(0.2 \mu \mathrm{M}, 10 \mathrm{Ci} /$ mmol New England Nuclear;) and $\mathrm{Fe}^{2+}$ and separating the free 5-HT from the bound form on Sephadex G-50, as previously described (Tamir et al., 1976; Tamir, 1982).

Isolation of the enteric SBP. $\left[{ }^{3} H\right] 5 H T$ complex. The longitudinal muscle with adherent myenteric plexus (LM-MP) was removed from the entire small intestine of one rabbit and incubated $\left(1 \mathrm{hr} ; 37^{\circ} \mathrm{C}\right)$ in Krebs solution $(20 \mathrm{ml})$ with $\left[{ }^{3} \mathrm{H}\right] 5-\mathrm{HT}(0.5 \mu \mathrm{M})$ in the presence of the monoamine oxidase (MAO) inhibitors, clorgyline $(10 \mu \mathrm{M})$ and pargyline $(0.1 \mathrm{mM})$, as well as the norepinephrine uptake inhibitor, desmethylimipramine (10 nM). Following incubation, the tissue was rinsed and removed to 5 $\mathrm{ml}$ of sucrose $(0.32 \mathrm{M})$ buffered with potassium phosphate buffer ( $1 \mathrm{mM}, \mathrm{pH}$ 7.5) to which the following proteolytic enzyme inhibitors were added: phenylmethylsulfonyl flu- 
oride (PMSF; $0.1 \mathrm{mM})$, EDTA $(0.2 \mathrm{~mm})$, pepstatin (1 $\mathrm{mM}$ ), and toluenesulfonyl-lysyl-chloromethyl ketone (3 $\mathrm{mM}$ ). The tissue was vigorously homogenized (Polytron, Brinkmann Instruments; $45 \mathrm{sec}$ ) and the homogenate was immediately centrifuged $(100,000 \times g, 30 \mathrm{~min})$. An aliquot $(0.5 \mathrm{ml})$ of the supernatant was applied to a Sephadex G-50 column and the $\left[{ }^{3} \mathrm{H}\right] 5-\mathrm{HT}$. SBP complex was separated from free $\left[{ }^{3} \mathrm{H}\right] 5-\mathrm{HT}$ as described above.

The complex of SBP $\cdot\left[{ }^{3} \mathrm{H}\right] 5-\mathrm{HT}$ was formed with protein extracted from the tissue in the following way. The LM-MP from rabbit small intestine was homogenized in $5 \mathrm{ml}$ of sucrose $(0.32 \mathrm{M})$ containing potassium phosphate buffer (1 mM, pH 7.5) and PMSF ( $2 \mathrm{mM}$ ) using a Polytron $(45 \mathrm{sec})$. The homogenate was centrifuged $(100,000 \times g$, $60 \mathrm{~min})$ and the supernatant was fractionated with $\left(\mathrm{NH}_{4}\right)_{2} \mathrm{SO}_{4}$. The fraction that precipitated between 0 and $30 \%$ saturation was centrifuged $(15,000 \times g, 15 \mathrm{~min})$. The pellet was dissolved in potassium phosphate buffer $(0.02 \mathrm{M}, \mathrm{pH} 7.5)$ and dialyzed against the same buffer, to which $10 \%$ glycerol had been added, for $18 \mathrm{hr}$. The dialyzed protein was used to prepare the complex as described previously (Tamir, 1982). Briefly, SBP (125 $\mu \mathrm{g})$ was incubated with $\mathrm{Fe}^{2+}(0.1 \mathrm{mM})$ and $\left[{ }^{3} \mathrm{H}\right] 5-\mathrm{HT}(2$ $\left.\times 10^{-7} \mathrm{M}\right)$ and the protein-bound $\left[{ }^{3} \mathrm{H}\right] 5-\mathrm{HT}$ was separated from free $\left[{ }^{3} \mathrm{H}\right] 5$-HT by molecular sieve chromatography on Sephadex G-50.

\section{SDS electrophoresis}

Electrophoresis on $10 \%$ polyacrylamide tube gels was carried out using the SDS buffer system of Laemmli (1970). For electrophoretic analysis, the protein or protein $\cdot \mathrm{Fe}^{2+} \cdot\left[{ }^{3} \mathrm{H}\right] 5$-HT complex was dissolved in a buffer containing $0.5 \mathrm{M}$ Tris- $\mathrm{HCl}(\mathrm{pH} 6.8), 0.05 \%$ SDS, $0.012 \%$ mercaptoethanol, $10 \%$ glycerol, and $2 \mathrm{~mm}$ EDTA. Following electrophoresis, the gels were either stained with Coomassie blue and destained as described by Fairbanks et al. (1971), or, to detect radioactivity, the gels were sliced (1-mm sections), placed in scintillation vials, and dissolved in tissue solubilizer TS- $1\left(0.4 \mathrm{ml}, 55^{\circ} \mathrm{C}\right.$ overnight; Research Products, Elkgrove, IL). After cooling, the sections were counted in a toluene-based scintillation fluid $(10 \mathrm{ml})$.

\section{Molecular weight estimation}

Estimates of molecular weight were made by SDS gel electrophoresis including the following standards: bovine serum albumin, $68 \mathrm{kd}$; tubulin, 55 to $57 \mathrm{kd}$; catalase, 60 $\mathrm{kd}$; and ovalbumin, $43 \mathrm{kd}$. The sources of these proteins were: bovine serum albumin and catalase, Calbiochem, La Jolla, CA; and ovalbumin, Pentex-Niles, Kankakee, IL; tubulin was a generous gift of Dr. D. Soifer. It is recognized that estimates of molecular weight based on SDS gel electrophoresis may be in error because SDS binding depends on the nature of the protein. Since no second method was used to verify the estimated molecular weight, we have referred to them as apparent molecular weights.

\section{Treatment of rats with p-chlorophenylalanine}

Rats (male, Sprague-Dawley, $300 \mathrm{gm}$ ) were injected with parachlorophenylalanine methyl ester (PCPA; 200 $\mathrm{mg} / \mathrm{kg}$, i.p., on 2 consecutive days). On the third day the rats were treated with clorgyline and perfused with $\left[{ }^{3} \mathrm{H}\right]$ 5-HT as described above.

Tryptophan-free diet. Rats (300 gm) were placed in individual cages. Control animals (5) received normal Purina Laboratory Chow (5001) and experimental animals (5) received a tryptophan-free diet prepared by Nutritional Biochemicals (Cleveland, $\mathrm{OH}$ ). Food and water were consumed ad libidum. Light-dark cycles of 12 $\mathrm{hr}$ were maintained identically for both groups. At indicated intervals a paired control and an experimental animal were treated with clorgyline and perfused through the lateral ventricles with $\left[{ }^{3} \mathrm{H}\right] 5-\mathrm{HT}$ for the estimation of the in vivo formation of the $\left[{ }^{3} \mathrm{H}\right] 5-\mathrm{HT}$. SBP complex as described above.

\section{Light microscopic radioautography}

Segments of ileum were removed from adult rabbits. The segments were equilibrated for $15 \mathrm{~min}$ in Krebs solution and then incubated for $30 \mathrm{~min}$ with $\left[{ }^{3} \mathrm{H}\right] 5-\mathrm{HT}$ $(0.5 \mu \mathrm{M})$. Tissues were fixed for $2.5 \mathrm{hr}$ in a hypertonic solution (Fischman and Gershon, 1964) of $2.0 \%$ glutaraldehyde, $2 \%$ formaldehyde (from paraformaldehyde), $0.5 \%$ acrolein, $0.5 \%$ dimethylsulfoxide, $3 \%$ sucrose, and $2 \mathrm{mM} \mathrm{CaCl}{ }_{2}$ in $0.1 \mathrm{M}$ sodium cacodylate buffer and, after a wash in buffer of not more than 5 min, postfixed for 1 $\mathrm{hr}$ in $1 \% \mathrm{OsO}_{4}$ (identically buffered). They were then rapidly dehydrated with ethanol, cleared in propylene oxide, and embedded in Epon 812. Alternatively, some material was embedded in paraffin. For this procedure postfixation in $\mathrm{OsO}_{4}$ was omitted. Rat brains that had been perfused with $\left[{ }^{3} \mathrm{H}\right] 5-\mathrm{HT}$ were treated identically except that tissues were fixed by transcardiac perfusion, first with $100 \mathrm{ml}$ of saline containing heparin and then with $500 \mathrm{ml}$ of fixative. After $20 \mathrm{~min}$, the fixed brains were removed and placed in fixative for an additional 2 $\mathrm{hr}$ prior to dehydration and embedding in paraffin.

For light microscopy, Epon sections, $1 \mu \mathrm{m}$ in thickness, or paraffin sections, $8 \mu \mathrm{m}$ in thickness, were cut and mounted on glass slides that had been precoated with gelatin containing $0.5 \mathrm{gm} /$ liter of chromium alum. The slides were then dipped in Ilford L4 emulsion (diluted 1:1 with water), dried, and exposed for 7 days under an atmosphere of $100 \% \mathrm{CO}_{2}$. Slides were developed for 5 min in Kodak D-19 developer, and after completion of photographic processing, Epon sections were stained with toluidine blue and paraffin sections were stained with cresyl violet. Slides were examined both by brightfield and darkfield microscopy.

\section{Electron microscopic (EM) radioautography}

Intestinal tissue that had been incubated with $\left[{ }^{3} \mathrm{H}\right] 5$ HT for analysis of the formation of the $\left[{ }^{3} \mathrm{H}\right] 5-\mathrm{HT} \cdot \mathrm{SBP}$ complex was also subjected to EM radioautography in order to determine possible sites of SBP localization. Incubated tissue was washed for $10 \mathrm{~min}$ in iced Krebs solution before fixation and after incubation in order to permit nonbound $\left[{ }^{3} \mathrm{H}\right] 5-\mathrm{HT}$ and radioactive metabolites to wash out of the tissue (Gershon and Ross, 1966a, b). Segments of LM-MP were then pinned flat and fixed for $2 \mathrm{hr}$ at room temperature in the same triple aldehyde solution used for light microscopic radioautography. Following extensive washing in buffer, the tissue was post- 
fixed in iced $3 \% \mathrm{KMnO}_{4}$ in Krebs-Ringer phosphate buffer $\left(\mathrm{CaCl}_{2}\right.$ replaced by $\mathrm{MgCl}_{2}$; Hokfelt, 1968) for 40 min. Tissues were stained en bloc with $0.1 \mathrm{gm}$ of magnesium uranyl acetate in $20 \mathrm{ml}$ of physiological saline, dehydrated in ethanol, and embedded in Spurr's low viscosity epoxy resin. Silver sections were placed on collodion-coated glass slides (Kopriwa, 1975). Some sections were stained with uranyl acetate and lead citrate, whereas others were not stained until after they had been picked up on grids. Sections were processed on this flat substrate with Ilford L4 photographic emulsion for EM radioautography as described previously (Gershon and Sherman, 1982). The combined aldehyde-permanganate procedure permits simultaneous visualization of $\left[{ }^{3} \mathrm{H}\right] 5$ HT (by radioautography) and noradrenergic varicosities (50-nm dense cored vesicles) in tissue (Gershon and Sherman, 1982).

Separation and assay of $\left[{ }^{3} \mathrm{H}\right] 5-\mathrm{HT}$ and its metabolite. The high speed supernatant obtained from either brain or gut whole homogenate was passed through a column of Sephadex G-10 (Boireau et al., 1976; Gershon and Tamir, 1981b).

\section{Assay of endogenous 5-HT and 5-HIAA using high pressure liquid chromatography}

The high pressure liquid chromatography system employed in these studies was the LC-50 (Waters Associates, Milford, MA), which was equipped with a Whatman Guard Column (Whatman Inc., Clifton, NJ), a Waters uBondapack C-18 reverse-phase column $(3.9 \times 30 \mathrm{~cm})$, and an LC-4A amperometric detector coupled to a TL-5 glassy carbon electrode (Bioanalytical Systems, West Lafayette, IN). Stainless steel tubing was used throughout. The mobile phase consisted of a sodium acetate buffer $(0.1 \mathrm{M}, \mathrm{pH} 4.7)$ containing $6 \%$ methanol (Reinhard et al., 1980). The flow rate was $2.0 \mathrm{ml} / \mathrm{min}$ and the column was operated at ambient temperature $\left(20^{\circ} \mathrm{C}\right)$. The electrochemical detector was set on a current-tovoltage gain (sensitivity) of $5 \mathrm{nA} / \mathrm{V}$, at a potential of 0.7 $\mathrm{V}$, with the recorder set to give a full scale deflection with $1 \mathrm{~V}$. All chemicals were of reagent grade. Water for the acetate buffer was deionized using a Millipore Milli$\mathrm{Q}$ water purification system (Millipore Corp., Bedford, MA).

Tissues were homogenized in $10 \mathrm{vol}$ of $0.1 \mathrm{M}$ perchloric acid containing $0.23 \mathrm{~mm}$ ascorbic acid (prepared fresh daily), using a Teflon-glass homogenizer (clearance $=$ $0.01 \mathrm{~mm}$ ). Homogenates were centrifuged at $15,000 \times \mathrm{g}$ and the clear supernatants were injected directly into the injection post of the liquid chromatograph.

\section{Results}

Formation of protein-bound $\left.{ }^{3} \mathrm{H}\right] 5-\mathrm{HT}$ in brain in vivo. In order to determine whether 5-HT is physiologically bound to SBP in vivo, exogenous $\left[{ }^{3} \mathrm{H}\right] 5$-HT was used as a probe. The labeled amine was perfused into the cerebral ventricles so that it could be taken up by central serotonergic neurons in vivo. It is known that $\left[{ }^{3} \mathrm{H}\right] 5-\mathrm{H} T$, taken up in this way, enters the physiologically releasable store of 5-HT (Chase et al., 1968; Jonakait et al., 1979). Following perfusion, the labeled brain was homogenized so as to liberate the contents of synaptic vesicles. We have previously demonstrated the lability of serotonergic synaptic vesicles under these conditions (Tamir and Gershon, 1979). The supernatant obtained from high speed centrifugation of the homogenate was passed through a molecular sieve column to separate bound from free $\left[{ }^{3} \mathrm{H}\right]$ 5-HT. The fraction containing the $\left[{ }^{3} \mathrm{H}\right] 5-\mathrm{HT}$ complexed to protein contained $4 \pm 1(\mathrm{SE}) \times 10^{5} \mathrm{cpm}(10$ experiments; 20 determinations) and comprised $15 \pm 3 \%$ (SE) of the total radioactivity present in the supernatant fraction. This protein-bound material was then subjected to $10 \%$ SDS-PAGE to identify the SBP. $\left[{ }^{3} \mathrm{H}\right] 5-\mathrm{H}$ T complex. We have previously shown that this complex is not completely dissociated by SDS under these conditions, and $\left[{ }^{3} \mathrm{H}\right] 5$ - $\mathrm{HT}$ moves with SBP and serves as a marker for the protein in electropherograms (Tamir et al., 1980; Tamir, 1982). The migration of the in vivo formed protein-bound $\left[{ }^{3} \mathrm{H}\right] 5-\mathrm{HT}$ on these gels was compared with that of $\left[{ }^{3} \mathrm{H}\right] 5-\mathrm{HT}$ complexed to partially purified SBP extracted from unlabeled whole brain. Two radioactive peaks were found (Fig. 1). These corresponded to apparent molecular weights of 56,000 and 45,000. As noted previously (Tamir et al., 1980), the $\left[{ }^{3} \mathrm{H}\right] 5$-HT complex with SBP extracted from brain also migrated with peaks corresponding to these same molecular weights; however, the 45-kd peak was dominant for the in vivo formed material (Fig. $1 A$ ), while the $56-\mathrm{kd}$ peak was dominant when the complex was formed with extracted whole brain SBP (Fig. 1B). Experiments were done to examine the molecular weights of the $\left[{ }^{3} \mathrm{H}\right] 5-\mathrm{HT}$ complex with SBP extracted from different regions of the CNS. The proportion of the 56 -kd form to the 45 -kd form was determined. The ratio, $56-\mathrm{kd}: 45-\mathrm{kd}$, was 7.7 in the forebrain, 7.0 in the raphe region, and 1.5 in the spinal cord. The 45 -kd form thus exists in fair quantity in at least one terminal field of serotonergic neurons, the spinal cord.

In these experiments it was found that significant quantities of protein-bound $\left[{ }^{3} \mathrm{H}\right] 5-\mathrm{HT}$ did not form unless the brain was perfused with $\left[{ }^{3} \mathrm{H}\right] 5-\mathrm{HT}$ for at least 3 $\mathrm{hr}$. Two intraventricular injections of labeled amine were not as effective in giving rise to protein-bound $\left[{ }^{3} \mathrm{H}\right] 5-\mathrm{HT}$ as continuous perfusion with, or at least five equally spaced injections of, the same quantity of labeled material. Pretreatment with a type A MAO inhibitor was essential. Failure to administer clorgyline resulted in complete oxidative deamination of perfused $\left[{ }^{3} \mathrm{H}\right] 5-\mathrm{HT}$ to $\left[{ }^{3} \mathrm{H}\right] 5$-HIAA. Since decreasing the time (to $15 \mathrm{~min}$ ) or speed (to $15,000 \times g$ ) of centrifugation of the whole homogenate increased the percentage of protein-bound $\left[{ }^{3} \mathrm{H}\right] 5$-HT 5 -fold, it is likely that either our homogenization procedure did not fully liberate the bound $\left[{ }^{3} \mathrm{H}\right] 5$ HT from vesicles, or the liberated material bound to membranes. SBP is hydrophobic and would be expected to so bind. We nevertheless used only the high speed supernatant for analysis to avoid contamination of our fractions with membranes.

Since homogenization liberates both free $\left[{ }^{3} \mathrm{H}\right] 5-\mathrm{HT}$ and SBP, it is possible that the complex between the two could form artifactually during or after homogenization. Conditions during homogenization were therefore made unfavorable for the formation of the complex in order to minimize this possibility. The homogenizing medium was kept at $4^{\circ} \mathrm{C}$ and was not fortified with $\mathrm{Fe}^{2+}$; nevertheless, 


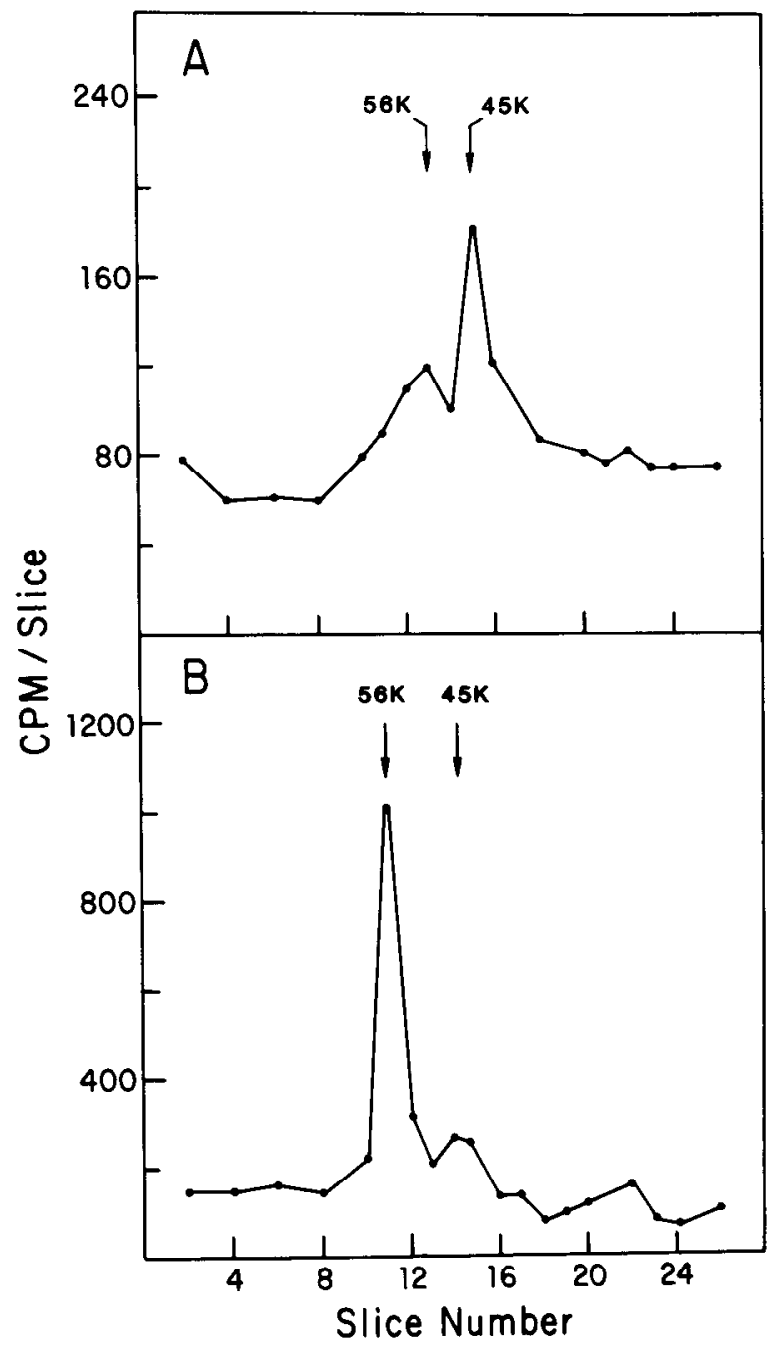

Figure 1. Identification of in vivo formed $\left[{ }^{3} \mathrm{H}\right] 5-\mathrm{HT} \cdot \mathrm{SBP}$ complex from the CNS. $A$, Protein-bound $\left[{ }^{3} \mathrm{H}\right] 5-\mathrm{HT}$ obtained by molecular sicve chromatography of an extract of $\left[{ }^{5} \mathrm{H}\right] 5-\mathrm{HT}$ perfused rat brain was subjected to $10 \%$ SDS-PAGE. Migration of radioactivity in the gels was assessed by cutting and counting $1-\mathrm{mm}$ slices of the gels. There is a radioactive peak that migrates with an apparent $M_{\mathrm{r}}$ of $45,000(45 \mathrm{~K})$ and a smaller shoulder corresponding to an apparent $M_{\mathrm{r}}$ of $56,000(56 \mathrm{~K}) . \mathrm{B}$, Nonperfused brain was homogenized and centrifuged $(100,000$ $\times g)$. The high speed supernatant was fractionated with $\left(\mathrm{NH}_{4}\right)_{2} \mathrm{SO}_{4}$, extensively dialyzed, and then incubated with $\left[{ }^{3} \mathrm{H}\right]$ 5-HT and $\mathrm{Fe}^{2+}$. The $\left[{ }^{3} \mathrm{H}\right] 5-\mathrm{HT} \cdot \mathrm{SBP}$ complex formed was then separated from free $\left[{ }^{3} \mathrm{H}\right] 5-\mathrm{HT}$ by molecular sieve chromatography and subjected to $10 \%$ SDS-PAGE as in $A$. The bulk of the complex formed with the extracted SBP migrates with an apparent $M_{\mathrm{r}}$ of 56,000 , but there is a smaller shoulder at 45,000 . This experiment was carried out five times.

a control was done to estimate the extent of postmortem formation of the $\left[{ }^{3} \mathrm{H}\right] 5-\mathrm{HT} \cdot \mathrm{SBP}$ complex. This control consisted of the addition of $\left[{ }^{3} \mathrm{H}\right] 5-\mathrm{HT}$ in a concentration slightly greater than that found in homogenates of perfused brain $\left(3 \times 10^{6} \mathrm{cpm}\right)$ to nonperfused brain just prior to homogenization. The control tissue was then treated in exactly the same way as was the experimental. Very little protein-bound $\left[{ }^{3} \mathrm{H}\right] 5-\mathrm{HT}$ could be detected under these conditions. The amount was 5 to $10 \%$ of that found in perfused brain and was too little to analyze by SDS-
PAGE. It is concluded that artifactual formation of the $\left[{ }^{3} \mathrm{H}\right] 5$-HT.SBP complex during or after tissue homogenization, if it occurs at all, is negligible.

Formation of protein-bound $\left[{ }^{3} \mathrm{H}\right] 5-\mathrm{HT}$ in the enteric nervous system (ENS). Enteric serotonergic neurons, like those of the CNS, contain SBP (Jonakait et al., 1977, 1979). To determine whether the $\left[{ }^{3} \mathrm{H}\right] 5-\mathrm{HT} \cdot \mathrm{SBP}$ complex is formed within these neurons in intact tissue, $\left[{ }^{3} \mathrm{H}\right]$ 5-HT was again used as a probe. In this case, advantage was taken of the high affinity, specific uptake of $\left[{ }^{3} \mathrm{H}\right] 5$ HT manifested by enteric serotonergic neurons (Gershon and Altman, 1971; Gershon et al., 1976; Gershon and Sherman, 1982). The dissected LM-MP was incubated with a low concentration of $\left[{ }^{3} \mathrm{H}\right] 5-\mathrm{HT}(0.5 \mu \mathrm{M})$ in the presence of MAO inhibitors and desmethylimipramine or excess nonradioactive 5-hydroxydopamine to prevent nonspecific uptake of $\left[{ }^{3} \mathrm{H}\right] 5-\mathrm{HT}$ by noradrenergic axons in the ENS. Under these conditions, uptake of $\left[{ }^{3} \mathrm{H}\right] 5$ HT has been shown to be exclusively into serotonergic axons (Gershon, 1982; Gershon and Sherman, 1982). Following incubation, the LM-MP was homogenized and subjected to centrifugation, and the high speed supernatant was fractionated by molecular sieve chromatography and analyzed by $10 \%$ SDS-PAGE as was done for $\left[{ }^{3} \mathrm{H}\right] 5$-HT-perfused brain. Again, protein-bound $\left[{ }^{3} \mathrm{H}\right] 5-$ HT was found ( $5 \pm 2(\mathrm{SE}) \times 10^{5} \mathrm{cpm} ; 6$ experiments; 12 determinations); moreover, as occurred with perfused brain, two peaks were resolved by SDS-PAGE corresponding to apparent molecular weights of 45,000 and 56,000 (Fig. 2). Once more, the peak at $45 \mathrm{kd}$ dominated (Fig. $2 A$ ). In the case of the gut, however, the 45 -kd peak is also dominant when the complex between patially purified SBP and $\left[{ }^{3} \mathrm{H}\right] 5-\mathrm{HT}$ is prepared from SBP extracted from the LM-MP (Fig. 2B; Gershon and Tamir, $1981 \mathrm{a}, \mathrm{b})$. In the case of the ENS, as well as the brain, inhibition of MAO, both types A and B, was found to be necessary to obtain protein-bound $\left[{ }^{3} \mathrm{H}\right] 5$-HT. It was also necessary to add protease inhibitors to LM-MP preparations prior to homogenization in order to preserve the $\left[{ }^{3} \mathrm{H}\right] 5-\mathrm{HT} \cdot \mathrm{SBP}$ complex formed within the intact neurons.

Location of $\left[{ }^{3} \mathrm{H}\right] 5-\mathrm{HT}$ in brain and gut prior to homogenization. In order to determine which structures could have been the source of the $\left[{ }^{3} \mathrm{H}\right] 5-\mathrm{HT}$ bound to SBP that was recovered from brain and ENS, radioautographic studies were done to ascertain where the $\left[{ }^{3} \mathrm{H}\right] 5$ HT had localized. Ventricular perfusion has been used by many investigators to label central serotonergic neurons specifically (Chan-Palay, 1975; Calas et al., 1976; Parent et al., 1981; Descarries et al., 1982); however, radioautography was done here to determine where the label was located under the conditions of our experiments. In the brain, the most intense labeling was found over periventricular regions and near the subarachnoid space (Fig. 3); nevertheless, examination of the radioautographs by darkfield microscopy revealed that, to some degree, regions quite distant from the surfaces of the brain contained radioactive material. Most of the labeling, however, was of terminal fields, although some cell bodies labeled also in the nuclei of the median raphe (Fig. 3, $C$ and $D$ ). No cell bodies were labeled in regions known not to contain serotonergic perikarya. These data 


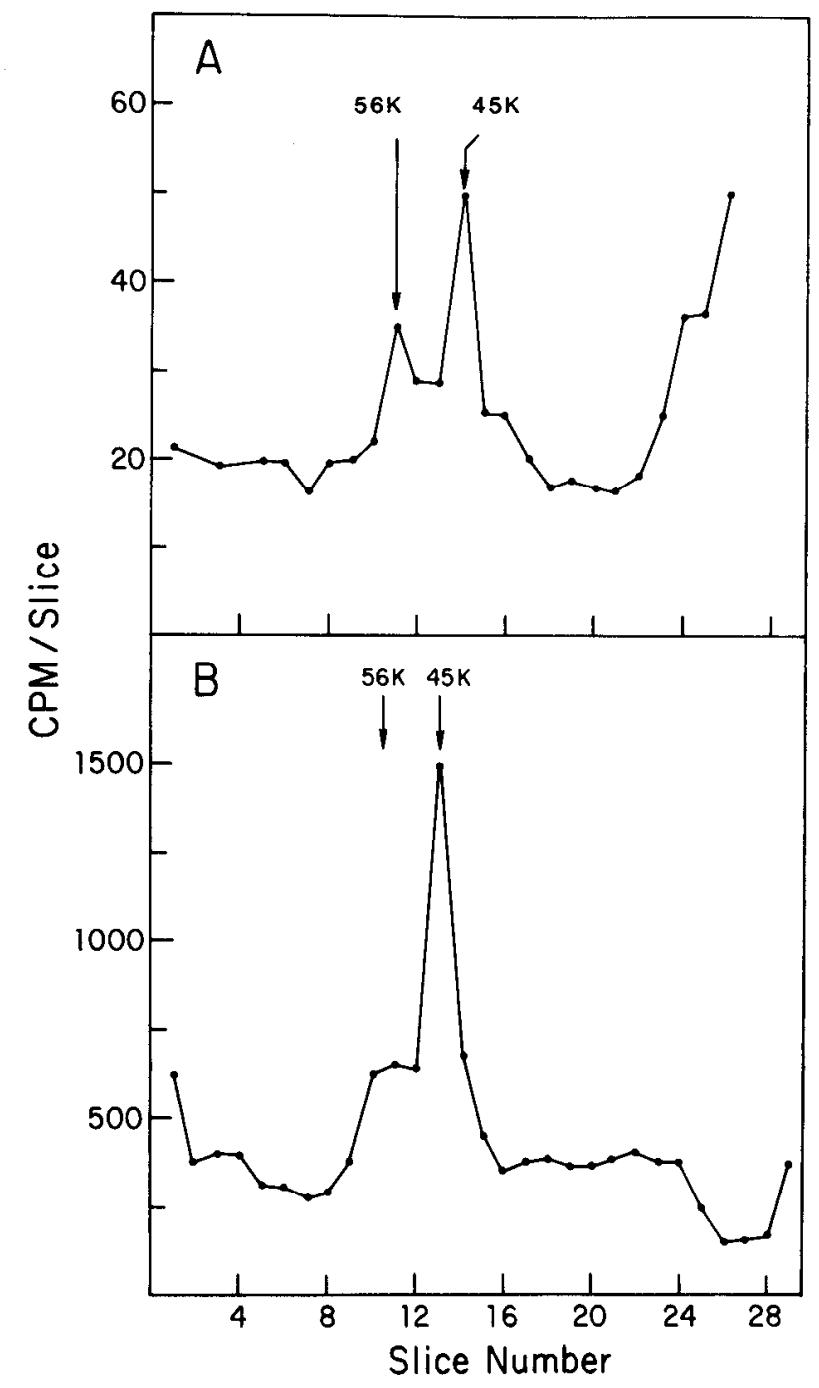

Figure 2. Identification of $\left[{ }^{3} \mathrm{H}\right] 5-\mathrm{HT} \cdot \mathrm{SBP}$ complex formed within intact neurons from the ENS. $A$, Protein-bound $\left[{ }^{3} \mathrm{H}\right] 5$ HT obtained by molecular sieve chromatography of extracts of rabbit ENS incubated with $\left[{ }^{3} \mathrm{H}\right] 5-\mathrm{HT}$ was subjected to $10 \%$ SDS-PAGE. Migration of radioactivity in the gels was assessed by cutting and counting $1-\mathrm{mm}$ slices of the gels. Two radioactive peaks can be seen, a major one corresponding to $45 \mathrm{kd}$ and a smaller peak at $56 \mathrm{kd}$. The rise in radioactivity near, and at the front, of the gel is due to either free $\left[{ }^{3} \mathrm{H}\right] 5$ - $\mathrm{HT}$ or $\left[{ }^{5} \mathrm{H}\right] 5-\mathrm{HT}$ bound to small proteolytic peptide fragments. $B$, Nonincubated ENS was homogenized and centrifuged $(100,000 \times g)$. The high speed supernatant was fractionated with $\left(\mathrm{NH}_{4}\right)_{2} \mathrm{SO}_{4}$, extensively dialyzed, and then incubated with $\left[{ }^{3} \mathrm{H}\right] 5-\mathrm{HT}$ and $\mathrm{Fe}^{2+}$. The $\left[{ }^{3} \mathrm{H}\right] 5-\mathrm{HT} \cdot \mathrm{SBP}$ complex formed with the extracted SBP was then separated from free $\left[{ }^{3} \mathrm{H}\right] 5-\mathrm{HT}$ by molecular sieve chromatography and subjected to $10 \%$ SDS-PAGE as in $A$. The bulk of the complex formed migrates with an apparent $M_{\mathrm{r}}$ of 45,000 , but there is a small shoulder at 56,000 as well. The experiment was carried out three times.

indicate that intraventricular perfusion with $\left[{ }^{3} \mathrm{H}\right] 5-\mathrm{HT}$ led to entrance of the tracer far more into axons and their terminals than into cell bodies and that regions nearest the ventricles and subarachnoid space were most radioactive. The penetration of $\left[{ }^{3} \mathrm{H}\right] 5-\mathrm{HT}$ into brain substance thus was not uniform and, consequently, the $\left[{ }^{3} \mathrm{H}\right] 5-\mathrm{HT} \cdot \mathrm{SBP}$ complex isolated from the $\left[{ }^{3} \mathrm{H}\right] 5-\mathrm{HT}$ perfused brain cannot be considered a uniform sample of the whole set of serotonergic structures of the CNS. The sample is derived, for example, more from axons than from cell bodies.

Penetration of $\left[{ }^{3} \mathrm{H}\right] 5-\mathrm{HT}$ into the myenteric plexus of dissected LM-MP preparations is not a problem. Both axons and cell bodies were found by EM radioautography to have been labeled in all parts of the plexus. The bulk of the labeling, however, was of axonal varicosities (Fig. 4). These labeled varicosities consisted of a single set of structures characterized by the presence of small, electron-lucent synaptic vesicles and large dense cored vesicles. This set of varicosities could readily be distinguished from noradrenergic varicosities which were not labeled by $\left[{ }^{3} \mathrm{H}\right] 5-\mathrm{HT}$ and which contain small dense cored synaptic vesicles. The $\left[{ }^{3} \mathrm{H}\right] 5-\mathrm{HT}$, following incubation of the ENS, thus was like the CNS, in that it predominantly labeled axonal varicosities and only to a lesser extent entered neuronal cell bodies. In preterminal axons, labeling by $\left[{ }^{3} \mathrm{H}\right] 5-\mathrm{HT}$ could be seen to be concentrated over regions rich in synaptic vesicles.

Formation of the $\left[{ }^{3} H\right] 5-H T \cdot S B P$ complex in vivo: Dependence on endogenous 5-HT levels. Previously it has been noted that SBP extracted from brain must be dialyzed free of endogenous 5-HT in order to assay the binding protein with $\left[{ }^{3} \mathrm{H}\right] 5-\mathrm{HT}$ (Tamir et al., 1976; Jonakait et al., 1977). This suggests that endogenous 5-HT is bound to SBP in vivo. If this is the case, then the capacity of SBP to bind exogenous $\left[{ }^{3} \mathrm{H}\right] 5-\mathrm{HT}$ in vivo may be limited by the amount of endogenous 5-HT already bound to the protein. In order to test this hypothesis, we sought to lower the endogenous 5-HT level, making the prediction that this procedure would increase the amount of protein-bound $\left[{ }^{3} \mathrm{H}\right] 5-\mathrm{HT}$ in brain following perfusion with $\left[{ }^{3} \mathrm{H}\right] 5-\mathrm{HT}$. The brain 5 -HT content was lowered by placing rats on a tryptophan-deficient diet to avoid the use of a drug, such as reserpine, that is known to affect SBP (Tamir et al., 1976; Jonakait et al., 1977). In addition to protein binding of $\left[{ }^{3} \mathrm{H}\right] 5-\mathrm{HT}$, the endogenous 5-HT and 5-HIAA concentration was also measured. Paired control (same chow with tryptophan) and experimental animals were perfused with $\left[{ }^{3} \mathrm{H}\right] 5-\mathrm{H} \mathrm{T}$ and killed, and their brains were analyzed identically. The tryptophan-deficient animals lost weight and their brains became depleted of 5-HT and 5-HIAA (Fig. 5). Protein-bound $\left[{ }^{3} \mathrm{H}\right] 5-\mathrm{HT}$, however, increased significantly in the tryptophan-deficient animals $(p<0.01$ compared to matched controls; Fig. 5). The increase in protein-binding capacity for $\left[{ }^{3} \mathrm{H}\right] 5-\mathrm{HT}$ was highest after 5 days of dieting and did not increase further up to 11 days; however, weight loss was extreme by this time.

An attempt was also made to deplete $5-\mathrm{HT}$ with the tryptophan hydroxylase inhibitor PCPA. This drug, however, inhibited the binding of $\left[{ }^{3} \mathrm{H}\right] 5-\mathrm{HT}$ to SBP, an effect that, unlike the action of PCPA treatment on tryptophan hydroxylase, could be reversed by dialysis. Nevertheless, these experiments were abandoned because the drug interacted with SBP so that no conclusions relevant to 5-HT levels and SBP binding could be drawn. 

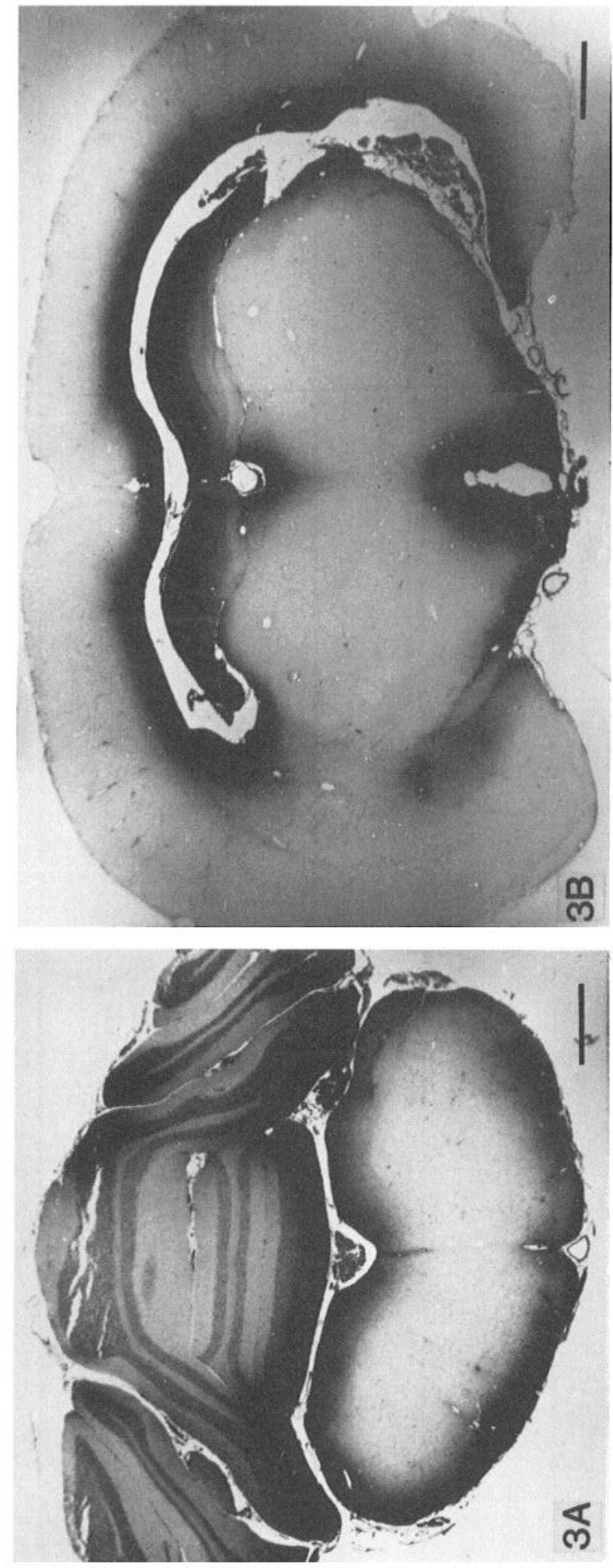

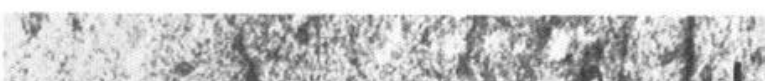

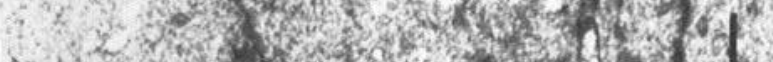

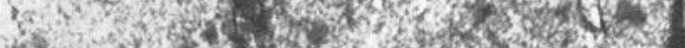

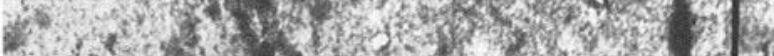

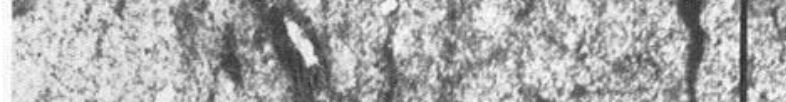

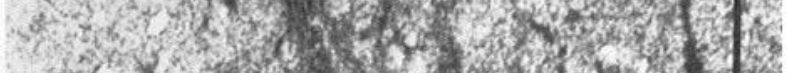

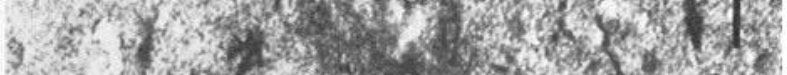

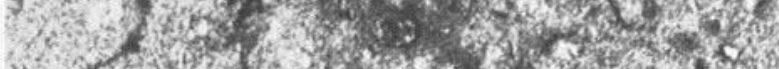
wer is

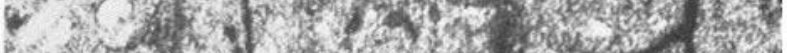

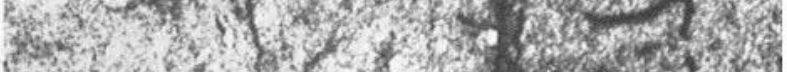

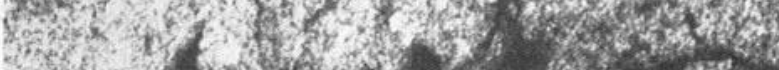

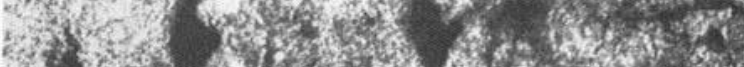

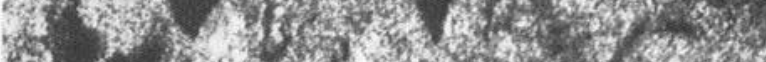

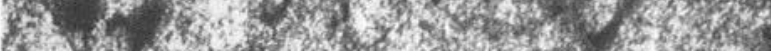

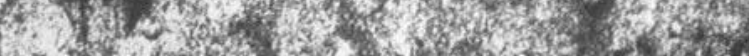

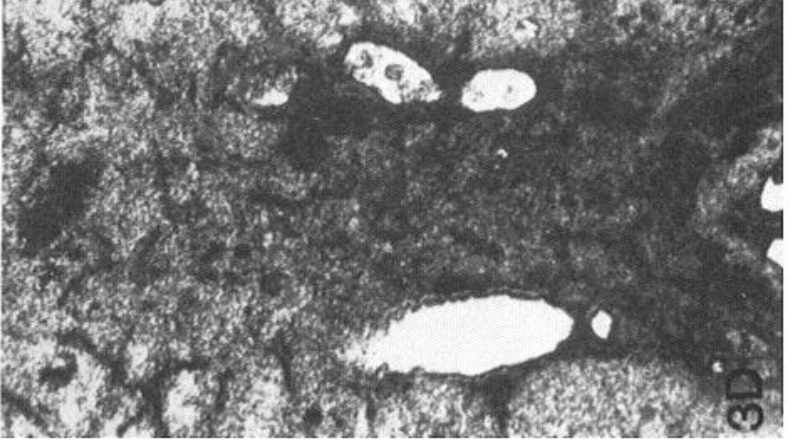

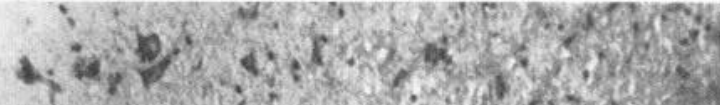

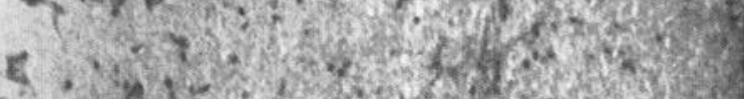

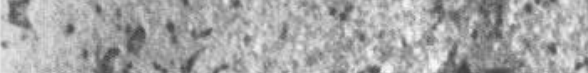

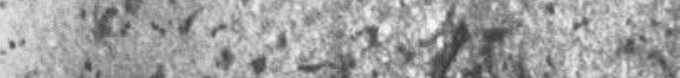

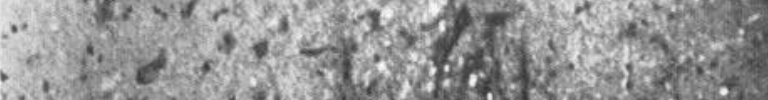

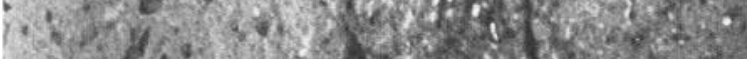

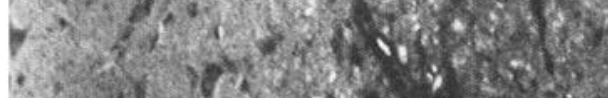
ard b. Het.

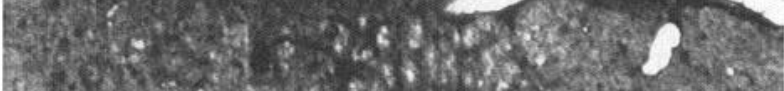

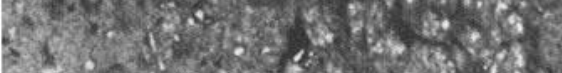

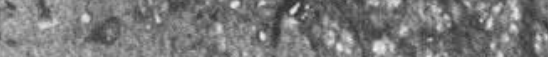

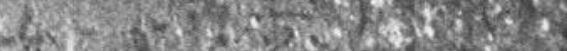

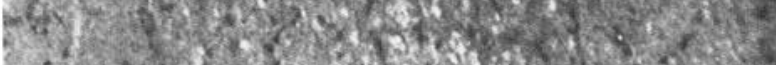

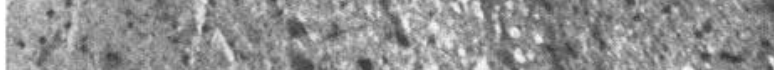
Wh

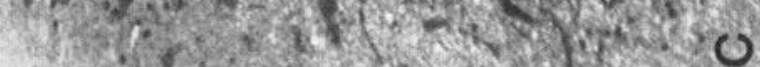

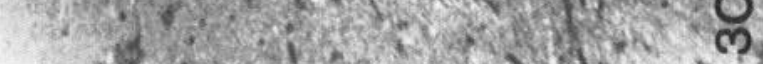

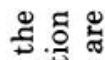

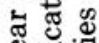

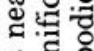

कू

घ्व

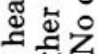

92.

舟

षे

क्षิ

멿 ๓ $\leq .5$

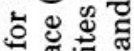
듕ํํ 巧。

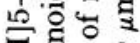
곤 귱

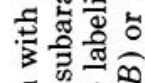

ีㅗㅀ

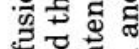
离. ค. 28 สิธิธี हี

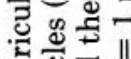

氙总㤩

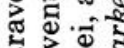
范 $\infty 0$ 중 芯 둥 重五

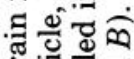

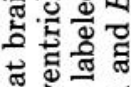
\% 돈 현 进焉 它玄芯 胥웛 녕 온 듕ํㅀ 东 ․ㅗㅇ 츨. 웡 옳융ㅇ

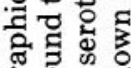

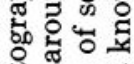
ㅋ. 웅

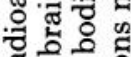
必 以苍苗.

ํำ ปี.

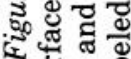
营 

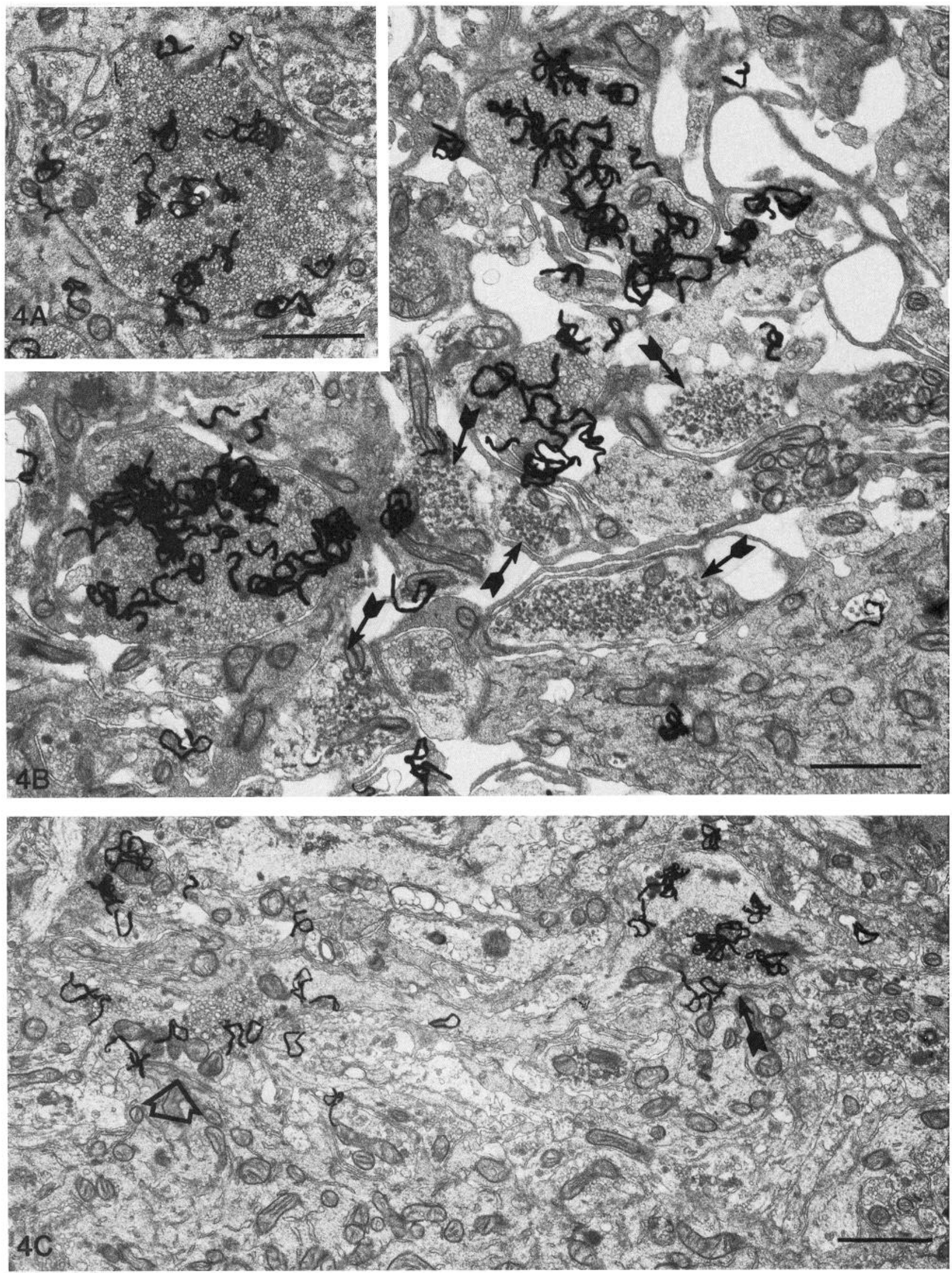

Figure 4. Electron microscopic radioautographs showing the location of $\left[{ }^{3} \mathrm{H}\right] 5-\mathrm{HT}$ in the myenteric plexus following incubation with $\left[{ }^{3} \mathrm{H}\right] 5$-HT under conditions similar to those used for the formation of the $\left[{ }^{3} \mathrm{H}\right] 5$-HT.SBP complex within intact neurons. An aldehyde-permanganate technique was used to permit the simultaneous recognition of enteric serotonergic (radioautographically labeled) and noradrenergic (40-nm dense cored vesicles) axons. A (inset), A single population of varicosities is labeled by 


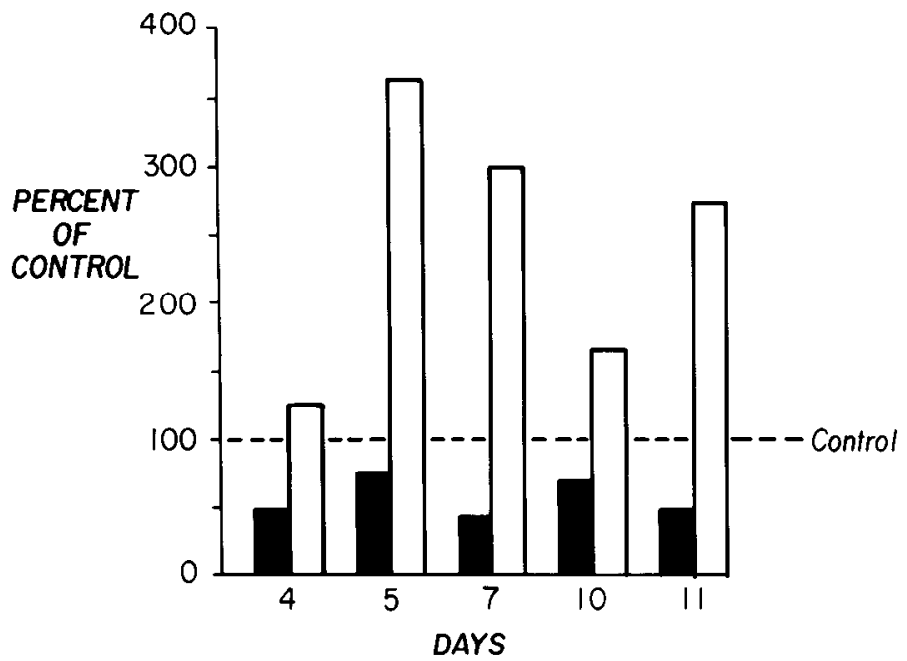

Figure 5. Effect of 5-HT depletion on in vivo binding of $\left[{ }^{3} \mathrm{H}\right]$ 5 -HT by SBP. Rats were placed on a tryptophan-deficient diet for periods of time indicated on the abcissa. The 5-HT concentration (solid bars) and the amount of $\left[{ }^{3} \mathrm{H}\right] 5-\mathrm{HT}$ bound in vivo to SBP following intraventricular perfusion (open bars) were determined. Results are expressed as percentage of control. Comparisons were made against rats fed a normal diet for the same period of time. Statistical tests between tryptophandeficient and control animals were done to evaluate the null hypothesis that differences at each time were due to chance. The null hypothesis was rejected; the tryptophan-deficient diet significantly lowered the concentration of 5 -HT $(p<0.05)$ and raised the binding of $\left[{ }^{3} \mathrm{H}\right] 5-\mathrm{HT}(p<0.01)$. The control $5-\mathrm{HT}$ concentration was $1.32 \mathrm{nmol} / \mathrm{brain}$ and binding of $\left[{ }^{3} \mathrm{H}\right] 5-\mathrm{HT}$ to $\mathrm{SBP}$ was $4.2 \times 10^{4} \mathrm{cpm} / \mathrm{mg}$ of protein.

\section{Discussion}

These experiments were undertaken in order to evaluate the physiological significance of SBP. The hypothesis was tested that $5-\mathrm{HT}$ is stored as a complex with the binding protein. $\left[{ }^{3} \mathrm{H}\right] 5$ - $\mathrm{HT}$ was used as a probe. The experimental paradigm consisted of presenting central and peripheral serotonergic neurons with $\left[{ }^{3} \mathrm{H}\right] 5-\mathrm{HT}$ and then determining whether any of the $\left[{ }^{3} \mathrm{H}\right] 5$-HT taken up by these neurons could be recovered as an in vivo formed complex with SBP. Molecular sieve chromatography and SDS-PAGE were used, respectively, to separate proteinbound from free $\left[{ }^{3} \mathrm{H}\right] 5-\mathrm{HT}$ and to identify the $\left[{ }^{3} \mathrm{H}\right] 5-$ $\mathrm{HT}$.SBP complex. Results indicated that the complex did, in fact, form in vivo. Protein bound $\left[{ }^{3} \mathrm{H}\right] 5-\mathrm{HT}$ was recovered both from brain perfused and ENS incubated with $\left[{ }^{3} \mathrm{H}\right] 5$-HT. In both instances, moreover, the proteinbound $\left[{ }^{3} \mathrm{H}\right] 5-\mathrm{HT}$ migrated on electropherograms as did $\left[{ }^{3} \mathrm{H}\right] 5-\mathrm{HT}$ complexed to authentic partially purified SBP, and SBP affinity labeled to the 5-HT-binding site with $N-\left[{ }^{14} \mathrm{C}\right]$ ethylmaleimide (Tamir et al., 1982). Addition of $\left[{ }^{3} \mathrm{H}\right] 5$-HT just prior to homogenization did not provide these results; therefore, the $\left[{ }^{3} \mathrm{H}\right] 5-\mathrm{HT} \cdot \mathrm{SBP}$ complex found in the in vivo experiments must have formed intracellularly, prior to homogenization, and thus was not an artifact of the method of analysis. These findings therefore support the hypothesis that $5-\mathrm{HT}$ entering serotonergic neurons becomes complexed to SBP.

It is noteworthy that partially purified SBP provides two distinct species when analyzed by SDS-PAGE corresponding to apparent molecular weights of 45,000 and 56,000 . It is possible that the $56-\mathrm{kd}$ form is a precursor of the 45-kd material. Partially purified 56-kd SBP spontaneously yields $45-\mathrm{kd}$ SBP when stored. This process is rapid at $37^{\circ} \mathrm{C}$, slower at $4^{\circ} \mathrm{C}$, and occurs even at $-20^{\circ} \mathrm{C}$ when the material is stored for over 4 weeks. Antibodies raised against the 56-kd SBP cross-react with the $45-\mathrm{kd}$ protein ( $\mathrm{H}$. Tamir, personal observations). Whatever the significance of the two forms of SBP, the observation that $\left[{ }^{3} \mathrm{H}\right] 5-\mathrm{HT}$ is preferentially recovered bound to 45 kd SBP when the complex is formed in vivo, whereas the $56-\mathrm{kd}$ material is dominant when the protein is extracted from whole brains, requires explanation. It seems likely that this apparent quantitative discrepancy is related to the nature of the procedure used to present the probe $\left[{ }^{3} \mathrm{H}\right] 5-\mathrm{HT}$ to SBP in vivo. Under the experimental conditions used, the $45-\mathrm{kd}$ SBP has preferential access to $\left[{ }^{3} \mathrm{H}\right] 5-\mathrm{HT}$. This phenomenon may, in turn, be related to the radioautographically demonstrated nonuniform distribution of $\left[{ }^{3} \mathrm{H}\right] 5-\mathrm{HT}$ in brain substance following ventricular perfusion or to the intracellular compartmentation of the two forms of SBP, or both. For example, the 45 -kd form of SBP may represent the form of the molecule in the synaptic vesicles of serotonergic varicosities. Varicosities of terminal axons probably account for the bulk of the uptake of $\left[{ }^{3} \mathrm{H}\right] 5$ - $\mathrm{HT}$ by brain and were found to be the major structure to be labeled by $\left[{ }^{3} \mathrm{H}\right] 5-\mathrm{HT}$ in the ENS. If vesicles contain the $45-\mathrm{kd}$ but not the $56-\mathrm{kd}$ material, therefore, the in vivo formed $\left[{ }^{3} \mathrm{H}\right] 5-\mathrm{HT} \cdot \mathrm{SBP}$ complex would mainly involve 45 -kd SBP. This may not reflect the total SBP pool, however, which also includes cell bodics and preterminal axons. The $56-\mathrm{kd}$ protein may predominate in these regions giving rise to the bulk of the unlabeled SBP that is extracted from homogenates of whole brain. The greater ratio of $56-\mathrm{kd}$ to $45-\mathrm{kd}$ SBP extracted from raphe regions in contrast to spinal cord is consistent with this interpretation. So too is the dominance of the $45-\mathrm{kd}$ form of SBP extracted under any circumstances from the ENS. In the myenteric plexus there are relatively few serotonergic cell bodies and only short stretches of preterminal axons, but there is a dense concentration of varicose terminal axons. Alternatively, the two forms of SBP may be stored in different serotonergic neurons that differ in regional distribution. Some may have more of the larger molecule while others may contain more of the smaller. The nonuniform distribu-

$\left[{ }^{3} \mathrm{H}\right] 5$-HT. It contains small round, electron-lucent and large dense cored synaptic vesicles. $B$, Serotonergic varicosities are heavily labeled and frequently encountered. Noradrenergic varicosities (arrows) can easily be distinguished from serotonergic or other terminals. They contain many $40-\mathrm{nm}$, rather pleomorphic synaptic vesicles, all of which contain a dense core (sometimes eccentrically located within the vesicle), but fewer large dense cored vesicles than are found in serotonergic varicosities. None of the noradrenergic varicosities have labeled with $\left[{ }^{3} \mathrm{H}\right] 5-\mathrm{HT}$. C, A serotonergic axon is sectioned longitudinally. Note that the labeling is concentrated over two varicose regions containing synaptic vesicles. These varicosities make an axodendritic (solid arrow) and an axosomatic (open arrowhead) synapse en passage. The scale markers $=1.0 \mu \mathrm{m}$. 
tion of $\left[{ }^{3} \mathrm{H}\right] 5-\mathrm{HT}$ perfused into the ventricles may in this case result in preferential uptake of $\left[{ }^{3} \mathrm{H}\right] 5-\mathrm{HT}$ by neurons that contain $45-\mathrm{kd}$ SBP. Further work is needed to distinguish between these possibilities. It will be particularly important to determine the relationship of the 56$\mathrm{kd}$ SBP to the 45-kd material. If the 56-kd SBP is, in fact, the precursor of the 45-kd SBP in all serotonergic neurons and is converted to the smaller form of the molecule by post-translational modification, the case for a difference between the two in intraneuronal distribution would be strengthened.

One additional possibility that must be considered is consistent with the data. It is known that there are multiple pools of 5-HT storage. Newly taken up and newly synthesized 5 -HT are preferentially released (Macon et al., 1971; Gershon and Tamir, 1981b). The labeling of the $45-\mathrm{kd}$ form of SBP by $\left[{ }^{3} \mathrm{H}\right] 5-\mathrm{HT}$ taken up by serotonergic neurons in vivo suggests that binding to the $45-\mathrm{kd}$ form may be involved in the storage of readily releasable 5 -HT. Conceivably, the 56-kd SBP may be complexed with the more stably bound 5-HT. The EM radioautographic results obtained from axons of the ENS that were sectioned en passage show that $\left[{ }^{3} \mathrm{H}\right] 5-\mathrm{HT}$ preferentially labeled regions containing accumulations of synaptic vesicles (Fig. 4). Portions of the same axons without vesicles were much less heavily labeled. The stimulated release of SBP, $\left[{ }^{3} \mathrm{H}\right] 5-\mathrm{HT}$, and endogenous 5-HT from the ENS have all been found to be $\mathrm{Ca}^{2+}$. dependent (Jonakait et al., 1979; Gershon and Tamir, 1981b). The location of $\left[{ }^{3} \mathrm{H}\right] 5-\mathrm{HT}$ in vesicles and the in vivo formation of a $45-\mathrm{kd}$ SBP $\cdot\left[{ }^{3} \mathrm{H}\right] 5-\mathrm{HT}$ complex in enteric axons, therefore, are consistent with vesicular storage of releasable 5 -HT together with 45-kd SBP. Such storage would explain the simultaneous release of SBP and 5-HT (Jonakait et al., 1979) as an exocytotic event.

The increase in in vivo binding of $\left[{ }^{3} \mathrm{H}\right] 5-\mathrm{HT}$ to SBP that occurred when the concentration of brain 5 - $\mathrm{HT}$ was lowered indicates that SBP must normally be nearly saturated with endogenous 5-HT. Curiously, the binding capacity of SBP for $\left[{ }^{3} \mathrm{H}\right] 5-\mathrm{HT}$ was increased proportionally more by serotonin depletion than can be accounted for by a linear correlation of binding capacity of SBP for $\left[{ }^{3} \mathrm{H}\right] 5-\mathrm{HT}$. This might mean that tryptophan deficiency depletes 5-HT bound to SBP more than total 5-HT. Alternatively, tryptophan deficiency may deplete other proteins at a faster rate than SBP so that binding capacity, which is expressed per milligram of total protein, appears to increase greatly. Other explanations of the nonlinear relationship can be envisioned; however, the fact that the increase occurs at all supports the view, albeit indirectly, that endogenous 5-HT is bound to SBP and competes with the $\left[{ }^{3} \mathrm{H}\right] 5-\mathrm{HT}$ probe for available binding sites.

It is concluded that SBP functions as a binding or storage protein for 5 -HT. The protein $\cdot 5-\mathrm{HT}$ complex is formed within serotonergic neurons in vivo. The role of the complex in the cellular biology of serotonergic neurons remains to be determined; however, reduction of osmotic pressure within synaptic vesicles is still a possibility.

\section{References}

Bernd, P., M. D. Gershon, E. A. Nunez, and H. Tamir (1981) Separation of dissociated follicular and parafollicular cells: Association of serotonin binding protein with parafollicular cells. J. Cell Biol. 88: 499-508.

Boireau, A., J. P. Ternaux, S. Bourgoin, F. Hery, J. Glowinski, and M. Hamon (1976) The determination of picograms levels of 5-HT in biological fluids. J. Neurochem. 26: 201-204.

Calas, A., M. J. Besson, G. Gaughy, G. Alonso, J. Glowinski, and A. Cheramy (1976) Radioautographic study of in vivo incorporation of ${ }^{3} \mathrm{H}$-monoamines in cat caudate nucleus: Identification of serotoninergic fibres. Brain Res. 118: 1-13.

Chan-Palay, V. (1975) Fine structure of labelled axons in the cerebellar cortex and nuclei of rodents and primates after intraventricular infusions with tritiated serotonin. J. Anat. Embryol. 148: 235-265.

Chase, T. N., G. R. Breese, D. O. Carpenter, S. M. Schanberg, and I. J. Kopin (1968) Stimulation induced release of serotonin. Adv. Pharmacol. 6: 351-364.

Descarries, L., K. C. Watkins, S. Garcia, and A. Beaudet (1982) The serotonin neurons in nucleus raphe dorsalis of adult rat: A light and electron microscope radioautographic study. J. Comp. Neurol. 207: 239-254.

Fairbanks, G., T. L. Steck, and D. F. H. Wallach (1971) Electrophoretic analysis of the major polypeptides of the human erythrocyte membrane. Biochemistry 10: 2607-2617.

Fischman, D. A., and M. D. Gershon (1964) A method for studying intracellular movement of water-soluble isotopes prior to radioautography. J. Cell Biol. 21: 139-143.

Gershon, M. D. (1982) Enteric serotonergic neurons. In Biology of Serotonergic Transmission, N. N. Osborne, ed., pp. 363399 , John Wiley \& Sons, New York.

Gershon, M. D., and R. F. Altman (1971) An analysis of the uptake of 5-hydroxytryptamine by the myenteric plexus of the small intestine of the guinea pig. J. Pharmacol. Exp. Ther. 179: 29-41.

Gershon, M. D., and L. L. Ross (1966a) Radioisotopic studies of the binding, exchange and distribution of 5-hydroxytryptamine synthesized from its radioactive precursor. J. Physiol. (Lond.) 186: 451-476.

Gershon, M. D., and L. L. Ross (1966b) Location of sites of 5 hydroxytryptamine storage and metabolism by radioautography. J. Physiol. (Lond.) 186: 477-492.

Gershon, M. D., and D. Sherman (1982) Selective demonstration of serotonergic neurons and terminals in electron micrographs: Loading with 5,7-dihydroxytryptamine and fixation with $\mathrm{KMnO}_{4}$. J. Histochem. Cytochem. 30: 769-773.

Gershon, M. D., and H. Tamir (1981a) Serotonin binding protein: Role in transmitter storage in central and peripheral serotonergic neurons. In Serotonin, B. Haber, S. Gabay, M. Issidorides, and S. Alivisatos, eds., pp. 37-49, Plenum Press, New York.

Gershon, M. D., and H. Tamir (1981b) Release of endogenous 5 -hydroxytryptamine from resting and stimulated enteric neurons. Neuroscience 6 : 2277-2286.

Gershon, M. D., R. Robinson, and L. L. Ross (1976) Serotonin accumulation in the guinea pig's myenteric plexus: Ion dependence, structure activity relationship and the effect of drugs. J. Pharmacol. Exp. Ther. 198: 548-561.

Gold, S., M. D. Gershon, and H. Tamir (1982) Comparison of serotonin binding proteins of neurons and enterochromaffin cells. Soc. Neurosci. Abstr. 8: 408.

Graftstein, B. (1977) Axonal transport: The intracellular traffic of the neuron. In Handbook of Physiology, J. M. Brookhart, V. B. Mountcastle, E. R. Kandel, and S. R. Geiger, eds. pp. 691-717, American Physiological Society Press, Bethesda, MD. 
Hokfelt, T. (1968) In vitro studies on central and peripheral monoamine neurons at the ultrastructural level. Z. Zellforsch. 91: 1-74.

Huang, Y. L., W. J. Kupsky, H. Tamir, and M. D. Gershon (1982) Serotonectin: A serotonin binding peripheral membrane glycoprotein of platelets is involved in platelet but not neuronal serotonin uptake. Trans. Am. Soc. Neurochem. 13: 132.

Jonakait, J. M., H. Tamir, M. M. Rapport, and M. D. Gershon (1977) Detection of a soluble serotonin binding protein in mammalian myenteric plexus and other peripheral sites of serotonin storage. J. Neurochem. 28: 277-284.

Jonakait, J. M., H. Tamir, A. R. Gintzler, and M. D. Gershon (1979) Release of serotonin and its binding protein by enteric neurons. Brain Res. 174: 55-69.

Kopriwa, B. (1975) A comparison of various procedures for fine grain development in electron microscope autoradiography. Histochemistry 44: 201-224.

Laemmli, U. K. (1970) Cleavage of structural proteins during the assembly of the head of bacteriophage $\mathrm{T}_{4}$. Nature 227 : 680-685.

Liu, K. P., H. Tamir, S. E. Karpiak, and M. D. Gershon (1982) Serotonin is stored as a complex with serotonin binding protein in situ. Soc. Neurosci. Abstr. 8: 489.

Macon, J. L., L. Sokoloff, and J. Glowinski (1971) Feedback control of rat brain 5-hydroxytryptamine synthesis. J. Neurochem. 18: 323-331.

Parent, A., L. Descarries, and A. Beaudet (1981) Organization of ascending serotonin systems in the adult rat brain. A radioautographic study after intraventricular administration of $\left[{ }^{3} \mathrm{H}\right]-5$-hydroxytryptamine. Neuroscience $6: 115-138$.

Reinhard, J. F., M. A. Moskowitz, A. F. Sved, and J. D. Fernstrom (1980) A simple, sensitive and reliable assay for serotonin and 5-HIAA in brain tissue using liquid chromatography with electrochemical detection. Life Sci. 27: 905911.

Tamir, H. (1982) Serotonin binding proteins. J. Histochem. Cytochem. 30: 837-840.

Tamir, H., and M. D. Gershon (1979) Storage of serotonin and serotonin binding in synaptic vesicles. J. Neurochem. 33: 3544.

Tamir, H., and Y. L. Huang (1974) Binding of serotonin to soluble binding protein from synaptosomes. Life Sci. 14: 8393.

Tamir, H., and M. J. Kuhar (1975) Association of serotonin binding protein with projections of the midbrain raphe nuclei. Brain Res. 83: 169-172.

Tamir, H., A. Klein, and M. M. Rapport (1976) Serotonin binding protein: Enhancement of binding by $\mathrm{Fe}^{+2}$ and inhibition of binding by drugs. J. Neurochem. 26: 871-878.

Tamir, H., W. Brunner, and D. Casper (1980) Enhancement of the binding of serotonin to serotonin binding protein (SBP) by gangliosides. J. Neurochem. 34: 1719-1724.

Tamir, H., R. Bebirian, F. Muller, and D. Casper (1981) Differences between intracellular platelet and brain proteins that bind serotonin. J. Neurochem. 35: 1033-1044.

Tamir, H., T. C. Theoharides, M. D. Gershon, and P. W. Askenase (1982a) Serotonin storage pools in basophil leukemia and mast cells. Characterization of two types of serotonin binding protein and radioautographic analysis of the intracellular distribution of ${ }^{3} \mathrm{H}$-serotonin. J. Cell Biol. 93: 638647.

Tamir, H., J. Barasch, F. S. Muller, and K. P. Liu (1982b) Serotonin storage: Identification of an essential sulfhydryl group and bicarbonate binding site in SBP. Trans. Am. Soc. Neurochem. 13: 245. 